\title{
Dosing Recommendations of Aripiprazole Depot with Strong Cytochrome P450 3A4 Inhibitors: A Relapse Risk
}

\author{
Martina Hahn' ${ }^{1}$ Sibylle C. Roll ${ }^{1}$
}

Published online: 3 May 2016

(C) The Author(s) 2016. This article is published with open access at Springerlink.com

\begin{abstract}
A 50-year-old male patient with comorbid human immunodeficiency virus developed a relapse of bipolar disorder after a switch from oral aripiprazole $10 \mathrm{mg} /$ day to intramuscular aripiprazole depot $200 \mathrm{mg}$ every 28 days plus oral aripiprazole $5 \mathrm{mg} /$ day. The patient was concomitantly taking lopinavir, saquinavir, ritonavir, silybum marianum extract, and omeprazole. Only 1 week after the switch, the patient developed mood swings, irritability, depressive mood, and lack of drive. The oral aripiprazole was increased again to stabilize the patient. The measured trough drug concentration of aripiprazole was low and may be correlated to the relapse. When oral aripiprazole was increased back to $10 \mathrm{mg}$ again, the depressive symptoms subsided. The dose of the next depot injection was increased to $300 \mathrm{mg}$ and that of oral aripiprazole decreased back to $5 \mathrm{mg} / \mathrm{day}$. Because trough drug concentrations were still low after 28 days, the depot dose was increased to $400 \mathrm{mg}$ every 28 days, which is double that recommended in the prescriber's information. Two months after the initial switch from oral to intramuscular aripiprazole, the patient's mood stabilized on aripiprazole depot $400 \mathrm{mg}$ every 28 days. More clinical data, especially regarding the pharmacokinetic drug interactions of aripiprazole depot are needed to improve dosing recommendations, and prevent relapses or adverse drug events. Genetic polymorphisms may play an important role in the clinical relevance of drug interactions concerning aripiprazole depot.
\end{abstract}

\section{Martina Hahn}

Martina.Hahn@vitos-rheingau.de

1 Vitos Klinik Eichberg, Kloster-Eberbach-Str. 4, Eltville 65346, Germany

\section{Key Points}

The dosing recommendation of intramuscular aripiprazole in the presence of cytochrome $\mathrm{P} 450$ inhibitors might need revision.

The pharmacokinetic drug interactions of intramuscular aripiprazole might only be clinically relevant in patients with the genetic polymorphism.

\section{Introduction}

Aripiprazole is a third-generation antipsychotic that is indicated (in the USA) in the treatment of schizophrenia, the acute treatment of manic and mixed episodes associated with bipolar I disorder, in irritability associated with autistic disorder, Tourette's disorder, and as an adjunctive treatment in major depression in adults. The recommended dosage in bipolar disorder is $15 \mathrm{mg} /$ day [1]. Drug interactions are a common potential problem with numerous medications used in psychiatry $[2,3]$. According to the aripiprazole package leaflet [4], the patients should inform their physicians that they are also taking human immunodeficiency virus (HIV) medications. HIV medications are inhibitors and inducers of cytochrome P450 (CYP) enzymes and, if taken concomitantly with aripiprazole, they can cause severe adverse drug events [5]. Ritonavir is a known strong inhibitor of CYP3A4 and a moderate inhibitor of CYP2D6 (Table 1), and, therefore, may decrease the metabolism of aripiprazole, a CYP3A4 and CYP2D6 substrate. Aripriprazole is primarily metabolized by CYP3A4 and CYP2D6, about $40 \%$ is metabolized to the active metabolite dihydroaripiprazole [6]. 
Table 1 CYP and P-gp metabolism of drugs being received by the patient, based on information from the MediQ.ch (http://www.mediq.ch) drug interaction database

\begin{tabular}{|c|c|c|c|c|}
\hline Drug & $\begin{array}{l}\text { Dose, duration of } \\
\text { treatment }\end{array}$ & Substrate of & Inhibits & Induces \\
\hline $\begin{array}{l}\text { Lopinavir/ } \\
\text { ritonavir }\end{array}$ & $\begin{array}{l}100 / 400 \mathrm{mg} \text { twice daily, } \\
\text { started } 2005\end{array}$ & $\begin{array}{l}\text { CYP3A4, CYP3A5, } \\
\text { CYP2D6 P-gp }\end{array}$ & $\begin{array}{l}\text { P-gp (moderate), CYP3A4 (strong), } \\
\text { CYP2D6 (moderate) }\end{array}$ & $\begin{array}{l}\text { CYP2B6, CYP1A2, } \\
\text { CYP2C9, CYP2C19 }\end{array}$ \\
\hline Saquinavir & $\begin{array}{l}1000 \mathrm{mg} \text { twice daily, } \\
\text { started } 2005\end{array}$ & CYP3A4, P-gp & $\begin{array}{l}\text { CYP3A4 (moderate), P-gp (moderate), } \\
\text { CYP2D6 (weak) }\end{array}$ & \\
\hline $\begin{array}{l}\text { Silybum } \\
\text { marianum } \\
\text { extract }\end{array}$ & $\begin{array}{l}179.85 \mathrm{mg} \text { once daily, } \\
\text { for years }\end{array}$ & CYP2C8 & CYP2C9 (moderate) & \\
\hline Omeprazole & $\begin{array}{l}40 \mathrm{mg} \text { once daily, for } \\
\text { years }\end{array}$ & CYP2C19, P-gp & $\begin{array}{l}\text { CYP2C19, CYP3A4 (weak), P-gp } \\
\text { (moderate) }\end{array}$ & CYP1A2, CYP1A1 \\
\hline Aripiprazole & $10 \mathrm{mg}$, started June 2015 & $\begin{array}{l}\text { CYP2D6, CYP3A4, } \\
\text { P-gp }\end{array}$ & P-gp (weak) & \\
\hline
\end{tabular}

CYP cytochrome P450, P-gp P-glycoprotein

The US prescribing information [1] of aripiprazole tablets recommends using only one quarter (in poor metabolizers) or one half (in extensive or intermediate metabolizers) of the regular dosage when administered concomitantly with a strong CYP3A4 inhibitor. Itraconazole, a strong inhibitor of CYP3A4, increased the area under the curve of oral aripiprazole by $50 \%$ [7]. The US prescribing information of aripiprazole depot [8] recommends an aripiprazole dosage of $300 \mathrm{mg}$ every 28 days when it is administered concomitantly with a strong inhibitor of CYP3A4 and of $200 \mathrm{mg}$ when administered concomitantly with CYP3A4 and CYP2D6 inhibitors.

In this case study, we report details regarding a patient with co-morbid bipolar disorder and HIV treated with ritonavir, saquinavir, and lopinavir who experienced a worsening of psychiatric symptoms when he was switched from oral to depot aripiprazole.

\section{Case Report}

A 50-year-old Caucasian male patient (body mass index $26 \mathrm{~kg} / \mathrm{m}^{2}$ ) with bipolar disorder (diagnosed 2007) and comorbid HIV infection was receiving treatment with intramuscular aripiprazole depot and HIV medications. He had HIV for 20 years and had previously experienced complications, including HIV-associated neurocognitive disorder, myopathy (creatinine kinase elevation to 199 $\mathrm{U} / \mathrm{L}$ ), pneumocystis pneumoniae, herpes simplex infections, and zoster oticus infection. He also had a history of chronic pain syndrome and arthritis, and was a smoker until 2011. He had been retired (owing to medical reasons) since 2006. His renal function was $99 \mathrm{~mL} / \mathrm{min}$ chronic kidney disease epidemiology collaboration equation in January 2015. He came to the psychiatric ambulatory care clinic in January 2015 for the first time. He presented with lack of concentration, lack of drive, mood swings, irritability, and anxiety, and was diagnosed with generalized anxiety disorder. At the time of the switch to intramuscular aripiprazole depot, he was receiving the prescription medications shown in Table 1. The patient had not been taking any over-the-counter medications.

We collected several serum concentrations of aripiprazole as shown in Table 2 (trough concentrations, liquid chromatography-mass spectrometry, blood collected in a tube without gel for plasma separation). The therapeutic reference range of aripiprazole according to the Arbeitsgemeinschaft für Neuropsychopharmakologie und Pharmakopsychiatrie (AGNP) consensus guideline [9] is $150-500 \mathrm{ng} / \mathrm{mL}$. The "therapeutic reference ranges" define ranges of medication concentrations that specify a lower limit below which a drug-induced therapeutic response is relatively unlikely to occur and an upper limit above which tolerability decreases or above which it is relatively unlikely that therapeutic improvement may be still enhanced. The therapeutic reference range is an orienting population-based range that may not necessarily be applicable to all patients [9].

On June 6, the patient started oral aripiprazole $5 \mathrm{mg}$ once daily. The dosage was increased to $10 \mathrm{mg} /$ day, with the patient reporting an improvement of all symptoms. The first concentration on aripiprazole $10 \mathrm{mg}$ was $94 \mathrm{ng} / \mathrm{mL}$ and hence within the expected dose-related plasma concentration range of $86-128 \mathrm{ng} / \mathrm{mL}$ (based on population data) according to the AGNP consensus guideline [9]. 
Table 2 Time line of the aripiprazole doses and drug concentrations

\begin{tabular}{lll}
\hline $\begin{array}{l}\text { Dose of aripiprazole } \\
\text { depot, mg (date) }\end{array}$ & $\begin{array}{l}\text { Dose of oral aripiprazole, } \\
\text { mg (date) }\end{array}$ & $\begin{array}{l}\text { Aripiprazole } \\
\text { concentration (ng/mL) }\end{array}$ \\
\hline & 5 (June 6-June 20) \\
10 (June 21-July 5) & 94 (July 6) \\
200 (July 6) & 5 (July 5-July 12) and 10 mg (July 13-August 2) & 143 (August 3) \\
300 (August 3) & 5 (August 3-31) & 95 (August 31) \\
300 (August 31) & 5 (August 31-September 28) & 95 (December 21) \\
400 (September 28) 400 (October 26) 400 (November 23) & & \\
\hline
\end{tabular}

On July 6, treatment was switched to aripiprazole depot $200 \mathrm{mg}$ plus oral aripiprazole $5 \mathrm{mg} /$ day. However, because of mood swings and a worsening of depressive symptoms, the dosage of oral aripiprazole was changed back to $10 \mathrm{mg} /$ day on July 13 . Owing to the unexpectedly low aripiprazole concentration of $94 \mathrm{ng} / \mathrm{mL}$ while the patient was receiving oral aripiprazole $10 \mathrm{mg} /$ day (Table 2 ), and the clinical worsening (depressive mood, mood swings, irritability) shown after the injection of $200 \mathrm{mg}$ plus oral $5 \mathrm{mg} /$ day (concentration $143 \mathrm{ng} / \mathrm{mL}$; Table 2), the dose for the second and third injection of aripiprazole was increased to $300 \mathrm{mg}$ and the oral dosage was kept at $5 \mathrm{mg} /$ day. At the day of the third injection (August 3), the aripiprazole concentration was $95 \mathrm{ng} / \mathrm{mL}$ (Table 2); oral aripiprazole medication was stopped, and the dose of the depot was increased to $400 \mathrm{mg}$ for the fourth injection. The patient's mood stabilized with aripiprazole depot $400 \mathrm{mg}$ every 28 days, and up to December 2015, no further pharmacotherapeutic intervention was needed; $400 \mathrm{mg}$ is double the recommended dose. The patient was monitored for adverse drug reactions and relapse symptoms twice every month. The concentration was $95 \mathrm{ng} / \mathrm{mL}$ on December 21.

The viral load of the patient was measured during that time and was negative (HIV1-RNA negative, T-helper cells $613 / \mu \mathrm{L}, \mathrm{CD} 4 / 8$ ratio 0.94 ), allowing us to verify the patient's compliance to the HIV medication.

\section{Discussion}

Dosing of aripiprazole depot accordingly to the prescribing information [1] may result in low drug concentrations and clinically worsening of symptoms with a risk for relapse, as shown in this case report. The low drug concentrations could be explained by a difference in pharmacokinetics: intravenous and intramuscular administered drugs do not undergo first-pass metabolism and have a bioavailability of $100 \%$, making drug interactions probably less clinically relevant. The aripiprazole concentrations with an oral dosage of $10 \mathrm{mg} /$ day were as high as those with intramuscular depot $300 \mathrm{mg}$ every 28 days plus oral $5 \mathrm{mg} /$ day, but still below the therapeutic range [9]. The low drug concentrations after the first injections could also be explained by the fact that the steady state after the injections is only reached after four to five injections. This would mean that the patients are at a relapse risk at least for the first month of the treatment with aripiprazole depot when treated with the recommended dosage.

Few data have been published (PubMed search, key words: aripiprazole + drug interactions) with regard to drug interactions with aripiprazole. One study found that therapeutic doses of lithium and divalproex had no clinically significant effects on the pharmacokinetics of oral aripiprazole in patients with schizophrenia or schizoaffective disorder [10]. In a study of aripiprazole, fluvoxamine, and paroxetine and the effects of genetic polymorphisms [11], the influence of CYP3A4 inhibition on the pharmacokinetics of aripiprazole was not considered clinically significant. However, interestingly, the researchers found a difference between intermediate and extensive metabolizers with regard to aripiprazole clearance (clearance decreased by 43 and $26.6 \%$, respectively), which could support the theory that a drug-drug interaction with aripiprazole is not clinically significant until the patient has a genetic polymorphism (intermediate or poor metabolizer). This finding might be relevant for our case and support the theory that our patient might be an extensive or ultra-rapid metabolizer for CYP2D6 substrates, so that drug interactions, even with strong inhibitors, such as HIV medications, did not cause clinically significant increases in drug concentrations: the aripiprazole concentration with oral aripiprazole $10 \mathrm{mg} /$ day and also aripiprazole depot $300 \mathrm{mg}$ plus oral aripiprazole $5 \mathrm{mg}$ were below the therapeutic range, even though strong inhibitors of CYP3A4 and CYP2D6 were present.

In another study conducted by Otsuka Pharma, co-administration of itraconazole decreased the clearance of aripiprazole in extensive metabolizers by $26.6 \%$, with an even greater decrease of $47.3 \%$ in intermediate metabolizers, but did not affect the peak plasma concentrations of aripiprazole. Overall, this drug interaction was not considered clinically significant [8]. 
This result, as well as those of our case report, does not support the manufacturer's dosing recommendation to decrease the dose of aripiprazole by $50 \%$ in presence of a strong CYP inhibitor. The recommendation seems to be too cautious and endanger the patient to relapse.

\section{Conclusion}

Without genetic testing or new dosing recommendations for aripiprazole depot, therapeutic drug monitoring is a reliable tool to assure drug therapy safety and efficacy of aripiprazole. The drug interactions caused by inhibition of CYP2D6 and CYP3A4 might not be clinically significant in every patient, and may depend on the genetic polymorphism of the patient. There are no published studies particularly on drug interactions of aripiprazole depot. The interactions of the intramuscular formulation might also not be clinically significant because of the different pharmacokinetics (no first-pass metabolism, higher bioavailability). More clinical data are needed to improve the dosing recommendations for aripiprazole depot.

\section{Compliance with Ethical Standards}

The patient gave written consent for this case report.

Conflict of interest Martina Hahn and Sibylle C. Roll declare that there are no conflicts of interest concerning the content of this case report.

Funding No financial support was received for the conduct of this case report or preparation of this manuscript.

Open Access This article is distributed under the terms of the Creative Commons Attribution-NonCommercial 4.0 International License (http://creativecommons.org/licenses/by-nc/4.0/), which permits any noncommercial use, distribution, and reproduction in any medium, provided you give appropriate credit to the original author(s) and the source, provide a link to the Creative Commons license, and indicate if changes were made.

\section{References}

1. Otsuka Pharmaceutical (2014). Abilify (prescribing information). Available from: http://www.otsuka-us.com/documents/Abilfy.PI. pdf. Accessed 16 Mar 2016.

2. Hahn M, Braus DF. Psychiatric polypharmacy: hazard through drug-drug interaction and possibilities for prevention. Versicherungsmedizin. 2012;64(3):127-31.

3. Hahn M. Wenn Wechselwirkungen den Therapieerfolg gefährden. Neurologie Psychiatrie. 2012;14(5):58-64.

4. Otsuka Pharmaceutical (2014). Abilify (package insert). Available from: http://packageinserts.bms.com/pi/pi_abilify.pdf. Accessed 16 Mar 2016.

5. Seden K, Merry C, Hewson R, et al. Prevalence and type of drugdrug interactions involving ART in patents attending a specialist HIV outpatient clinic in Kampala, Uganda. J Antimicrob Chemother. 2015;70(12):3317-22.

6. Kirschbaum KM, Muller MJ, Malevani J, et al. Serum levels of aripiprazole and dehydroaripiprazole, clinical response and side effects. World J Biol Psychiatry. 2008;9(3):212-8.

7. Kubo M, Koue T, Inaba A, et al. Influence of itraconazole coadministration and CYP2D6 genotype on the pharmacokinetics of the new antipsychotic aripiprazole. Drug Metab Pharmacokinet. 2005;20(1):55-64.

8. Otsuka Pharmaceutical (2015). Abilify Maintena (prescribing information). Available from: http://www.otsuka-us.com/ products/Documents/Abilify.M.PI.pdf. Accessed 16 Mar 2016.

9. Hiemke C, Baumann P, Bergemann N, et al. AGNP Consensus guidelines for therapeutic drug monitoring in psychiatry: update 2011. Pharmacopsychiatry. 2011;44(6):195-235.

10. Citrome L, Josiassen R, Bark N, et al. Pharmacokinetics of aripiprazole and concomitant lithium and valproate. J Clin Pharmacol. 2005;45:89-93.

11. Azuma J, Hasunuma T, Kubo M, et al. The relationship between clinical pharmacokinetics of aripiprazole and CYP2D6 polymorphism: effects of CYP enzyme inhibition by coadministration of paroxetine and fluvoxamine. Eur $\mathrm{J}$ Clin Pharmacol. 2012;68(1):29-37. 